\title{
Deterring Defiance: 'Don't Give a Poacher a Reason to Poach'
}

Matthew R. Filteau, Ph.D.

Agricultural Economics, Sociology and Education

The Pennsylvania State University

301 Armsby Building

University Park, Pennsylvania 16802

mrf219@psu.edu

Contact author - Matthew R. Filteau: mrf219@psu.edu; 010 814-360-0013

\begin{abstract}
Poaching threatens species biodiversity and ecological integrity, but criminologists largely overlook this form of crime. The purpose of this study is to expand criminological theory on poaching by documenting the strategies poachers and game wardens suggest as successful deterrents. Defiance theory is used to understand how the interaction between game wardens and poachers is an important consideration for garnering voluntary compliance. Qualitative interviews with game wardens $(\mathrm{N}=16)$ and poachers $(\mathrm{N}=13)$ demonstrate that these parties ideologically agree about fish and wildlife conservation, and both parties offer similar methods for deterring poaching. However, because poachers are negatively disposed toward indiscriminant game wardens, the perception of unfair treatment/punishment may lead to future poaching. This study examines trajectories for future research on poaching and contributes to contemporary criminological theory by linking defiance theory with deterrence theory. Finally, the paper concludes with strategies for deterring poaching and garnering voluntary compliance.
\end{abstract}

\section{Keywords: Poaching, Game Wardens, Defiance Theory, Deterrence Theory, Voluntary Compliance}




\section{Deterring Defiance: 'Don't Give a Poacher a Reason to Poach' - Filteau}

\section{Introduction}

An increasing amount of social science research focuses on the phenomenon of poaching, and conservation law enforcement. ${ }^{1}$ Although little information exists on the global effects of poaching, early research argues that effective policies are critical for protecting wildlife resources and maintaining an ecological balance (Musgrave et al. 1993; Muth \& Bowe 1998). Other studies examining particular species, areas, and the worldwide demand for illegally harvested animals conclude that poaching is pervasive, and it threatens global biodiversity and ecosystems around the world (Musgrave \& Stein 1993; Muth 1998; Rosen \& Smith 2010; Warchol 2004; Warchol et al. 2003). The commodification of and global demand for certain species, or animal parts is a primary driver for poaching, and threatens species from Africa (Lemieux 2011) to the United States (Musgrave \& Stein 1993).

However, despite recent attention by researchers, and a trend toward the re-enchantment of humans and the natural world (Gibson 2009), some crimes against nature still fail to excite public outrage. Poaching, or the illegal taking of fish and/or wildlife, is one of these crimes. Poaching is common, relatively unstigmatized, differentially treated by the legal system, and lacks a human victim; therefore, it is sometimes conceptualized as "folk crime" (Forsyth et al. 1998; Muth 1998; Ross 1961). Muth (1998) comments that law enforcement officials treat poaching as a minor offense, similar to other folk crimes-littering, gambling, minor traffic violations and jay walking. From a criminal law standpoint, poaching violations are mala prohibita, rather than mala in se-whereby the list of conservation laws/ regulations vary by statute, rather than being inherently wrong and universally denounced (Beirne \& Messerschmidt 2006, 13). And although there are instances where individuals and communities denounce poaching of iconic animals (see Colomy \& Granfield 2009), examples of this outrage are rare.

Despite societal and moral disregard for the legitimacy of poaching, and its potential to threaten biodiversity, recent attention within sociological and criminological research on poaching largely overlooks how to deter poachers from committing fish and wildlife violations. Building from Eliason's (2008) theoretical and empirical foundation, the goal of this study is to understand strategies for deterring poaching. I use a sample of game wardens and poachers from the state of Maine to understand how traditional conservation law enforcement may undermine its primary goal—voluntary compliance—by inciting poacher defiance against game wardens, and creating incentives for future poaching. Drawing from criminological literature on defiance and deterrence, this article contends that the generalist role among game wardens may prove more effective as a deterrent approach for poaching than traditional conservation law enforcement. The qualitative data I present reinforce the literature by documenting the strategies poachers and game wardens perceive as useful for deterring poaching. I conclude by suggesting new and alternative trajectories that advance the theoretical and empirical knowledge for research on poaching and conservation law enforcement. 


\section{Literature Review}

\section{Poaching}

Research on poaching largely builds on two interrelated theories of how crime is learned and neutralized. First, differential association explains how family and friends play an integral role in the socialization process that leads to poaching (Curione 1992; Eliason 1999; Forsyth 1993; Forsyth \& Marckese 1993a, 1993b; Green 1990). Poachers are orientated into illegal behavior by people close to them, and they often become entrenched in a culture where breaking fish and wildlife laws is normal (Green 1990). Second, researchers make connections between differential association and neutralization theory, because during the process of learning illegal behavior, poachers also learn techniques of neutralization that make it acceptable to commit fish and wildlife violations (Sykes \& Matza 1957). Although some poachers are members of subcultures, or commit more serious crimes, including violent crime and theft (Green 2002), poachers are often members of conventional society who rely on techniques of neutralization to justify their illegal acts (Curione 1992; Eliason 1999, 2003, 2004; Eliason \& Dodder 1999, 2000; Forsyth \& Marckese 1993a, 1993b; Forsyth et al. 1998; Green 2002; Muth 1998; Muth \& Bowe 1998).

Muth and Bowe's ten-part typology specifying the motivations for poaching largely contributes to research identifying the neutralizations poachers use (See Muth \& Bowe 1998). Building from this framework, Eliason and Dodder $(1999,2000)$ identify four neutralizations frequently used by poachers: denial of responsibilities (Poachers claim their offenses were accidental), the metaphor of the ledger (Their good qualities make up for their poaching), the defense of necessity (They needed the meat to survive), and condemnation of the condemners (They poached because of negative dispositions toward legal authority). Important for this study is this final neutralization. Poachers commit fish and wildlife offenses because they disagree with specific regulations, and/or the officers issuing a summons. Therefore some poachers commit fish and wildlife violations for pleasure, to outsmart game wardens, or as rebellion against certain wardens (Muth \& Bowe 1998; Eliason \& Dodder 1999, 2000). The seduction of crime (Katz 1988) for some poachers derives from demonstrating superior local knowledge and hunting skills (Forsyth \& Marckese 1993; Forsyth 1993). Interactions between game wardens and poachers are possible sources of contention, as are the legitimacy of conservation laws and officers.

\section{Conservation Law Enforcement}

The roles and responsibilities of conservation agencies and officers are changing. Once, game wardens solely enforced the fish and wildlife laws/regulations intended to conserve natural resources and maintain a healthy ecological balance, but these officers are no longer specialized. They now provide generalist law enforcement services, and their responsibilities are akin to traditional police (Falcone 2004). In addition to fish and wildlife law enforcement, game 


\section{Deterring Defiance: 'Don't Give a Poacher a Reason to Poach' - Filteau}

wardens are now authorized to perform search and rescue, education through outreach, enforce recreational vehicle, motor vehicle, and watercraft laws, make arrests for and drug and alcohol violations, and ensure public safety (Chavez \& Tynon 2000; Eliason 2011; Eliason 2007a; Eliason 2011; Filteau 2008; Pendelton 1996; O'Connor \& Crow 2009; Sherblom et al. 2002). The warrantless search authority among game wardens was once perceived as excessive (O'Connor 1986) because of their specialization in conservation law enforcement, but now many agencies have the same enforcement authority as other state and municipal law enforcement agencies.

Research on game wardens draws many parallels between traditional policing and conservation law enforcement. Like other forms of police work, conservation law enforcement is hazardous (Forsyth \& Forsyth 2009; Forsyth \& Marckese 1993b; Palmer \& Bryant 1985; Walsh $\&$ Donovan 1984). The general law enforcement responsibilities among wardens contribute to assault rates 2.5 times those of state police; this danger compels them to draw a firearm 4 times the rate of state police (Carter 2004). Perhaps making their job more hazardous than other law enforcement officers, conservation officers often work alone, and poachers are armed and sometimes willing to use firearms, knives or other gear to escape apprehension (Carter 2004; Forsyth \& Marckese 1993a). Adding to the difficulty of their work, fish and wildlife violations receive differential treatment by the court system (Eliason 2011), meaning some wardens may perceive the risk of physical injury as unnecessary when courts are lenient with suspected poachers.

Similar to traditional police, conservation officers must understand their local context and communicate effectively with the public. Although neither poaching nor conservation law enforcement is confined to rural areas; it is largely regarded as a rural crime. And while most game wardens come from rural areas (Palmer \& Bryant 1985; Sherblom et al. 2002), some researchers claim these wardens better understand rural tradition, enabling them to use discretion more wisely (Forsyth and Forsyth 2009).

Discretion is an important part of conservation law enforcement because establishing intent (mens rea) may be difficult in poaching cases. State and federal laws vary within a state, region, or area; therefore, suspected poachers often claim they did not know the law where they were issued a summons (Eliason 2003). An officer's disposition toward using discretion varies greatly, and some officers are conceptualized as bookers, and others as peacemakers (Forsyth1994). Under this dichotomy, bookers are indiscriminate wardens who abide by the book and issue citations to nearly everyone suspected of poaching, and peacemakers are officers who use discretion to establish intent and issue warnings when there is a discrepancy in the evidence. Paired with the changing role of legal authority in conservation law enforcement agencies and discretion, defiance theory is useful for understanding how conservation law enforcement strategies may increase poaching, rather than create the intended deterrent effect. 


\section{Deterring Defiance}

Garnering voluntary compliance for fish and wildlife laws becomes increasingly important as game wardens face additional workloads, more generalist police responsibilities, limited funding, and the heightened risks associated with the job. Hunting license revocation, incarceration and public shaming via newspaper reports are credited as useful deterrent strategies (Musgrave et al. 1993), but social science research on how to deter poaching will benefit from deterrence theory's (re)conceptualization of specific and general deterrence, and punishment and punishment avoidance.

Deterrence prevents illegal behavior through fear of legal punishment (Gibbs 1975), and there are two ways people are deterred from crime. First, general deterrence or one's indirect experience with punishment means the knowledge that some people are punished will deter the general population from illegal activity; second, specific deterrence deals with one's direct experience with crime and punishment, meaning individuals are punished for a crime they commit and it deters them from future crime (Stafford \& Warr 1993). The certainty of punishment or one's ability to avoid punishment (punishment avoidance) may influence one's decision to commit crimes. Deterrence theory argues, when a person's perceived level of punishment avoidance is high, one believes getting away with a crime is more likely; therefore, one is more apt to deviate because the evidence suggests direct punishment is unlikely. Therefore, punishment avoidance may become more influential for encouraging future crime, than punishment is for discouraging it (Stafford \& Warr 1993). Other evidence suggests that punishment further increases the likelihood of crime (Piquero \& Pogarsky 2002), meaning punishments may create defiance.

Defiance theory (Sherman 1993) is useful for demonstrating three effects of sanctioning: it can become a deterrent to future law breaking; it can provoke defiance of the law; or it can become irrelevant to future law breaking. The theory proposes that there will be a "net increase in the prevalence, incidence or seriousness of future offending against a sanctioning community caused by a proud, shameless reaction to the administration of a criminal sanction" (Sherman 1993, 459). This theory relies on four necessary conditions: (1) the sanction must be perceived as unfair; (2) the offender is alienated from society and authoritative agents; (3) the sanction is viewed as stigmatizing; (4) the offender does not internalize the shame associated with the sanction (Sherman 1993).

Sherman (1993) incorporates reintegrative shaming (Braithwaite 1989), shame and rage (Scheff \& Retzinger 1991), and procedural justice (Tyler 1990) to advance his theory of defiance. While reintegrative sanctions may create a deterrent effect, disintegrative sanctions may produce defiance by stigmatizing the offender, and weakening social bonds with the community (Hirschi 1969); weaker bonds thereby make it easier to neutralize illegal behavior (Sykes \& Matza 1957). Therefore, the sanction does not have the effect of direct deterrence as 


\section{Deterring Defiance: 'Don't Give a Poacher a Reason to Poach' - Filteau}

suggested by Stafford \& Warr (1993); rather, the punishment increases the likelihood of future crime (Piquero \& Pogarsky 2002). The final element, procedural justice, is a matter of treating offenders (or suspects) with dignity and respect (Tyler 1990). Rude, disrespectful police officers reduce their own legitimacy and the legitimacy of the criminal justice system (Tyler 1990; Sunshine \& Tyler 2003). The perception of fairness - either by arresting officers or judgesoften depends on whether these officials are willing to hear the offender's viewpoint; and if so, this has a deterrent effect on future acts of illegal behavior (Tyler 1990). Therefore, voluntary compliance depends on legitimate laws and law enforcement officials who use reintegrative rather than disintegrative sanctions.

\section{Methodology}

\section{Study Location}

Maine's biodiversity and rural landscape contribute to its rich sporting tradition. The state is 30,843 square miles (nearly as large as the other five New England States combined), but has a small population density - approximately 43 people per square mile (Census 2012). During data collection for this study, the Maine Warden Service employed 125 sworn personnel, including 94 game wardens located in 12 law enforcement districts across the state. The Warden Service is responsible for enforcing laws pursuant to fish and wildlife conservation, Title 17a (Maine's criminal statues), Title 29a (Maine's driving laws), and are solely responsible for search and rescue within the state.

Sampling: This study analyzes in-depth qualitative interviews to understand the strategies poachers and game wardens perceive as useful for deterring poaching. A snowball sampling method allowed me to gain access to two types of poachers (Creswell 2006): individuals who were sanctioned after breaking fish and wildlife laws when harvesting animals $(\mathrm{N}=6)$, and poachers who successfully avoided punishment $(\mathrm{N}=7)$. All poachers were white men, Maine residents, and between the ages of twenty-five to sixty-two years of age. The occupations of the respondents varied - two of the respondents owned or were major partners in their place of employment, while eleven were employed as laborers, fabricators, commercial fishermen, health care assistants, salesmen, construction workers, and car mechanics.

I purposively selected game wardens by their experience levels (number of years on the job), and whether they worked in developed $(\mathrm{N}=8)$ or rural $(\mathrm{N}=8)$ districts (Miles \& Huberman 1994). I interviewed sixteen active and retired game wardens ranging in experience from $8 \frac{1}{2}$ to 42 years - two retired, but still deputized wardens are included in the sample. All game wardens in the sample are white men with at least a high school education.

Data Collection: Data collection occurred during January and February 2008. I conducted semi-structured interviews, and allowed respondents to speak for themselves, which allowed me to understand their perceptions of poaching and poachers. I created detailed descriptions of each 
experience, and summarized and interpreted the data. This approach is known as interpretive interaction, a method focused on the study and imputation of meaning, motive, emotion, intention and feeling through the life experiences of interacting individuals (Denzin 1978). Thick descriptions of how each respondent viewed poaching and legal authority were captured in field notes, and open and selective coding revealed themes in the transcripts (Geertz 1973).

Interviews were approximately one hour, were audio recorded and transcribed verbatim. I met participants in public spaces such as coffee shops and restaurants for interviews; however, some took place in the participants' residences or offices. One participant (poacher) invited me to ice fish with him - this interview took place in the respondent's ice shack located on a remote trout pond that we accessed by snowmobile.

\section{Findings}

Most poachers express a negative disposition toward some fish and wildlife laws, game wardens and their enforcement tactics. This is true for prosecuted poachers and those able to avoid legal sanctions. The following quotes are from two poachers: first a convicted poacher, and the second quote is from a poacher able to avoid punishment. Both are disgusted with game wardens and their policing tactics:

I think they're assholes. I mean, they have too much power to do what they should do. They do entrapment, they steal from you, they promise you and shake your hand, like they're God's gift to whoever, and they're no different than a common thief, and most of them are poachers-that's how they know where we're going.....If you can't even trust your own law enforcement, who can you trust?

Some can be pretty inconsiderate, and they approach you in an inconsiderate manner. Smelting this past year they approached me and my boys and it was really irrelevant: he was asking them, 'are these your smelts?' 'Did you dip your own?' He was all over these kids and it was really irrelevant, there was no need of it. ${ }^{2}$

These quotes emphasize the negative dispositions held by poachers toward game wardens, because of their treatment in the field. Negative dispositions result from interactions in the field, even during standard law enforcement practices like checking a bag limit of smelt. These statements confirm that standard check-ups, when perceived negatively, violate a poacher's sense of justice. Poachers perceive treatment by wardens as procedural injustice (Tyler 1990), and the enforcement practices used by game wardens as hostile, and entrapment. 


\section{Deterring Defiance: 'Don't Give a Poacher a Reason to Poach' - Filteau}

\section{Wardens \& Legal Authority}

Officers utilize a high degree of discretion when deciding to issue a summons or a warning. Often the difficulty of establishing intent for fish and wildlife violations requires game wardens utilize strategies that help determine intent and therefore the appropriate amount of discretion. The primary way game wardens establish intent is by watching suspected poachers.

That's why game wardens watch people. That's why I sit in the bushes with binoculars. This is the purist example, artificial lures: if you're fishing with a worm, I'm watching you the whole time. Are you looking over your back? Are you hiding the bait? The way you're using it indicates intent and that at face value indicates that person may have known better.

To determine if the offense is a deliberate violation or negligence, wardens will watch suspected poachers for suspicious behavior that may reveal intent. Wardens also admit, "Offending history, like it or not, will come into play." Therefore suspected poachers with a history of illegal fish and wildlife violations are more likely to receive citations when they are suspected of crimes, than those without a prior record, especially when intent is in question. Maine game wardens also use discretion when enforcing basic laws for the protection of public safety and natural resources.

In my mind there are some violations, safety violations, you don't dub around with. If you're driving with a loaded gun, you get a ticket; if a guy is drinking and hunting, that guy gets a ticket; if a guy is out in a canoe in May and doesn't have a PFD, he gets a ticket. ${ }^{3}$

The severity of the law or regulation broken, and the importance of knowing and following these laws for ensuring public safety and conserving the resource are important factors for game wardens when issuing a summons or warning suspects. In cases where the law or regulation is broken unintentionally, and officers determine a suspect's negligence was a minor infraction, officers will often give a verbal warning. Discretion depends on a number of factors, and the consequences for using too much or too little discretion are largely unknown. After receiving a warning or a summons, the incident can have three effects; create compliance, defiance, or have no impact (Stafford and Warr 1993). For poachers in this study, the determination of unfair treatment encourages defiance.

\section{Defiant Poachers}

Respondents have different reactions during and after encountering game wardens. While some express acceptable treatment by game wardens, most express their frustration, lack of trust, 
and even anger after interacting with wardens. Others defy the law because they perceive treatment as unfair. One poacher comments:

I think the older wardens have a real good sense of fairness..... I think the most misunderstood aspects of poaching, for the younger wardens, is don't give a poacher a reason to poach. He's already got enough reasons in his mind, don't give him another one. I guess if there's any honor among thieves, I try not to show up guys that I have respect for. I'm more cognizant of their area and more cognizant of their district.....Absolutely, less likely to violate there out of respect for them.

When interactions with game wardens are perceived as fair, or procedurally just, a deterrent effect is created. For some poachers, this deterrent effect is limited to the district of a warden perceived as fair. Poachers may continue to violate, but generally their illegal behavior is confined to districts patrolled by wardens they perceive as unfair. Experience is an important factor in a poacher's perception of fairness-game wardens with more experience are seen as better able to use discretion wisely, whereas less experienced wardens who abide by the book are viewed as unjust.

\section{Poachers' Deterrent Strategies}

Despite their willingness to poach, participants in this sample believe taking animals in an excessive amount is poaching. Poachers also believe in conservation-preventing the excessive harvest of fish and wildlife is imperative because it threatens animal populations. This influences how each poacher perceives poaching; overall, poachers are negatively disposed toward poaching. A convicted poacher articulates this negative disposition:

You don't need the poacher that's out there poaching 50 or 60 deer a year, and selling them. You don't need him. And there are also poachers who I know, and I don't respect them, who have broken every law while shooting an animal: they shot him at night, they shot him on posted land, they shot him with a light, they shot him out of season, and then they turn around and left it there. Now that's the kind of poacher that even a poacher is against.

Despite being negatively disposed toward legal authority, poachers in this sample perceive the excessive harvesting, commercial poaching, thrill killing and violating multiple laws during the act of poaching as legally and morally wrong. When asked how to prevent or deter fish and wildlife violations, most poachers overwhelmingly suggest pro-criminal justice solutions. 


\section{Deterring Defiance: 'Don't Give a Poacher a Reason to Poach' - Filteau}

Make the punishment more severe; don't give him a week at the crow bar hotel with cable TV and three hot meals.....Stricter, scarier sentences would definitely deter.

Up the fines-that creates a financial obligation to what you're doing.

Poachers support stricter sanctions for garnering voluntary compliance-either by increasing fines, or by imposing longer, harder sentences. These respondents do not reject criminal justice solutions for the prevention of crime. In fact, most unconvicted and convicted poachers believe that more game wardens would help reduce poaching.

Well if they made the penalty ludicrous, you'd be taking a chance. But poaching, especially fishing, man, there aren't enough game wardens. You have to be an idiot to get caught. You have to be abusing it, or you have to be fucking up real bad.

The game wardens should be more visible. They shouldn't try to wait until the crime is committed. They should stop it before it occurs. Wardens can prevent a lot of crime before it occurs by being seen. Now they wait for a complaint and catch people rather than stopping it.

The budgetary constraints of the Maine Warden Service concerned poachers, and the paucity of game wardens in the field contributed to heightened punishment avoidance levels (Stafford \& Warr 1993). The reactive law enforcement strategy of waiting for someone to commit a crime, rather than proactively preventing it through visibility concerns poachers. Therefore, the strategies game wardens use for establishing intent are perceived as reactive instead of proactive-poachers believe this approach contradicts natural resource conservation. Proactive strategies like visibility and education also reduce the likelihood of punishment avoidance. Other poachers argue " . . it is a combination of [more] game wardens, but also...teaching kids and the young hunter who has never hunted to hunt the right way. It's respect, and respect is important." Therefore preventing poaching requires proactive measures that differ from the traditional reactive law enforcement role. Education and reducing a poacher's sense that they will avoid punishment for their crimes are proactive strategies poachers endorse.

However, not all poachers believe poaching can be prevented through stricter sanctions, respect, and more game wardens. One convicted poacher felt it is impossible to prevent poaching:

I don't know if there is anything that can be done to prevent it. They've raised the price of fines; they've raised the jail time, and people still do it. I don't know that there is anything you can do to prevent it. 
This participant alludes to the inevitability that people will deviate from the law, despite efforts by the Warden Service to raise fines and jail time. After spending three years in a state prison, this poacher is currently paying over $\$ 7,000$ in fines for his offenses. He argues stricter sanctions will not prevent poaching because “. . . like I say, I didn't think I was going to get caught.” Therefore if poachers don't feel they will be apprehended for their offenses, raising the jail sentence and fines will not deter individuals from poaching-with few wardens, poachers more easily experience punishment avoidance (Stafford \& Warr 1993).

\section{Game Wardens' Deterrent Strategies}

Game wardens and poachers agree on deterrent strategies and preventative measures; however, because of unique responsibilities within a warden's district, there are inconsistencies among game wardens. Overall, game wardens from developed and rural districts differ on how they perceive their primary job responsibility: wardens from rural districts see their role as law enforcement, while wardens from developed districts prioritize public relations. These differences influence how a warden perceives deterrent strategies for poaching. The following two quotes illustrate the differential perspectives of game wardens from rural and developed districts, respectively:

I'll tell you what the biggest thing is, it's already been done: the loss of hunting licenses. Guys will go to jail, pay the \$1,000 fines, but they don't want to lose their hunting rifle, or their hunting license.

It has to be respect. You have to earn their respect, not only as a law enforcement officer, but for the ideals that your organization represents. If they believe in you, and believe in your organization they won't do it. And I've had a few people that have said to me 'you know what [name of warden], I use to violate fish and game laws all the time, but since I met you I won't do it anymore.' That should be the goal, voluntary compliance.

Game wardens from rural districts see their primary responsibility as law enforcement; consequently, they also favor stricter punishments to deter future poaching. However, wardens in developed districts who perceive their primary responsibility as public relations, suggest respect and fairness as the principle deterrent strategies for reducing future poaching. ${ }^{4}$

It is unclear how each punishment will affect voluntary compliance, but based on information from poachers: if offenders are weakly bonded (Hirschi 1969), treated unfairly (Tyler 1990) and sanctioned, they may poach without a license in the future (Piquero \& Pogarsky 2002). Therefore establishing voluntary compliance through trust and procedural justice provides a proactive way to combat poaching, while punishments such as license and equipment revocations may provoke defiance (Piquero \& Pogarsky 2002; Sherman 1993). 


\section{Deterring Defiance: 'Don't Give a Poacher a Reason to Poach' - Filteau}

\section{Discussion}

Although poaching threatens ecosystems and species biodiversity, little research and theory focuses on this crime. The present study integrates defiance and deterrence theory with current research and theory on poaching and conservation law enforcement to understand how treatment of poachers by game wardens may garner voluntary compliance. Interviews with thirteen poachers and sixteen game wardens in the state of Maine provide an understanding of the punitive sanctions and non-judicial methods poachers and game wardens perceive as effective for deterring poaching (Eliason 2008).

Data from this study reveal that poachers are negatively disposed toward legal authority, but both game wardens and poachers suggest pro-criminal justice solutions as preventative strategies for poaching, and creating voluntary compliance. Poachers develop negative dispositions toward legal authority when fish and wildlife laws, and the enforcement officials responsible for upholding those laws, violate their sensibilities of fairness (Tyler 1990). Most poachers express a negative disposition toward unfair legal authority, unjust enforcement tactics, and poor treatment by game wardens during interactions or when being apprehended for suspected crimes. Practices such as observing suspected poachers and waiting for illegal behavior to occur, and unfair treatment and rudeness upon apprehension serve to delegitimize individual wardens, the Maine Warden Service and the laws they represent.

However, similar to research in other states (Eliason 2003; Forsyth 1994), Maine game wardens face challenges when establishing intent. Therefore, they must observe the public for suspicious behavior. Discretion becomes an integral part of establishing intent, and the decision process when deciding whether to issue a summons or a warning. Wardens evaluate the severity of the infraction, the suspect's previous offense history, the threat to health and safety, and the detriments to the resource. Evidence suggests that interactions between poachers and conservation officers may depend on the wardens' perception of their primary job responsibility. Wardens from developed districts who see their primary job responsibility as public relations are akin to peacemakers, while wardens who see their primary role as law enforcement fit the conceptualization of bookers (Forsyth 1994). It is unclear how these perceptions influence interactions between poachers and game wardens, or if the methods these wardens use to apprehend suspected poachers differ. Future research should examine how wardens from different regions perceive their primary role, and how they handle encounters with suspected poachers and people engaged in legal recreation.

How wardens use discretion is important, because interactions between poachers and game wardens are a catalyst for strengthening or weakening social bonds (Hirschi 1969; Sherman 1993) and legitimizing or delegitimizing game wardens and the laws/regulations they represent. Once deligitimization occurs, poachers are apt to defy legal authority, and they more easily rationalize their illegal behavior (Eliason and Dodder 1999, 2000; Muth and Bowe 1998; Sykes 
and Matza 1957). The perception of disintegrative sanctions and unfair interactions between poachers and game wardens creates defiance among some poachers, rather than the intended deterrent effect (Sherman 1993). Interestingly, poachers in this study are not negatively disposed toward all wardens or legal authority, just officers they perceive as unfair. These statements speak to the importance of trust, fairness and procedural justice for garnering legitimacy and voluntary compliance (Tyler 1990; Tyler \& Huo 2002).

It is unclear from this study what effect, if any, punishing poachers for their crimes has as a general deterrent or punishment avoidance for the general population, but poachers do advocate stricter penalties will deter poaching. Secondly, it is unclear how certain punishments create specific deterrence effects or punishment avoidance among convicted poachers (Stafford \& Warr 1993). Evidence from this study suggests punishments perceived as unfair increase the likelihood of crime (Piquero \& Pogarsky 2002); although, future research using experimental designs would provide more robust tests of defiance theory.

Ironically, despite their negative disposition toward game wardens that are unfair, poachers are also negatively disposed toward poaching. As a result, poachers offer pro-criminal justice solutions and non-punitive punishments to deter fish and wildlife violations-increasing fines, stricter prison sentences; and staffing issues such as increasing the number of game wardens in the field and encouraging wardens to be proactive. Perhaps one of the most important considerations for punishment avoidance is the one identified by poachers: a lack of visible game wardens.

\section{Conclusion}

Evidence from this research suggests multiple strategies are necessary to deter poaching, because as Muth and Bowe (1998) outline, the motivations among poachers vary; therefore, so should preventative measures. While trust, fairness and procedural justice ('being nice') are important elements; they may not work on the most egregious offenders. To address these perpetrators, it becomes necessary to decrease their perception of punishment avoidance. Many states have adopted anonymous reporting programs to decrease punishment avoidance. For example, the "Turn in a Poacher" (TIP) initiative in Pennsylvania and Operation Game Theft (OGT) in Maine, but these programs do ". . . very little to prevent poaching" (McSkimming \& Berg 2008: 240). Conservation law enforcement agencies must pair this strategy with educational programs that promote ethical hunting and angling, proper techniques, and information on poaching's ecological harm. These strategies further relegate conservation officers to more generalist roles (Falcone 2004), reduce definitions favorable to criminal behavior, and increase informal social control among hunters, anglers and non-consumptive recreationalists (Heberlein 1991). Therefore generalist roles among game wardens may deter poaching more than exclusively relying upon conservation law enforcement. To avoid blanket regulations and garner voluntary compliance, conservation law enforcement agencies should 
form partnerships with conservation organizations (Stretesky et al. 2010), and local communities (Hampshire et al. 2004; Allison 2001). Conservation law enforcement agencies employing multiple deterrent strategies will decrease punishment avoidance among poachers with different motivations, garner voluntary compliance, and mitigate poaching. 


\section{Endnotes}

The terms "conservation officers" and "game wardens" are used interchangeably.

Freshwater smelt are caught with nets or hand lines for bait or human consumption.

Personal Floatation Device (PFD)

Because of the diversity in years of experience among wardens patrolling rural and developed regions, it is unclear from this study's data if there are differences among wardens with different experience levels.

\section{Acknowledgements}

Contributions from anonymous reviewers were invaluable for developing this paper's conceptual framework. Also, I am grateful for the time and care April Gunsallus invested while reviewing this manuscript. Special thanks are extended to Andrea Leverentz for her continued support. 


\section{Deterring Defiance: 'Don't Give a Poacher a Reason to Poach' - Filteau}

\section{References}

Allison, E.H. 2001. Big laws, small catches: global ocean governance and the fisheries crisis. Journal of International Development 13, 933-950.

Beirne, P., \& J. W. Messerschmidt. 2006. Criminology. Los Angeles, California: Westview Press.

Braithwaite, J. 1989. Crime, shame, and reintegration. Cambridge, UK: Cambridge University Press.

Carter, T. 2004. Force by and against game wardens in citizen encounters. Police Quarterly 7, 489-508.

Carter, T.J. 2006. Police use of discretion: a participant observation study of game wardens. Deviant Behavior 27, 591-627.

Chavez, D.J. \& J.F. Tynon. 2000. Triage law enforcement: Societal impacts on national forests in the west. Environmental Management 26, 403-407.

Colomy, P., \& R. Granfield. 2010 Losing Sampson: Nature, crime, and boundaries. The Sociological Quarterly 51, 355-383.

Creswell, J. W. 2007. Qualitative Inquiry and Research Design. $2^{\text {nd }}$ ed. California: Sage Publications.

Curcione, N. R. 1991. Deviance as delight: Party-boat poaching in Southern California. Deviant Behavior 13, 33-57.

Denzin, N. 1978. The Research Act. New York: McGraw- Hill.

Eliason, S.L. 2011. Policing natural resources: Issues in a conservation law enforcement agency. Professional Issues in Criminal Justice 6,43-58.

Eliason, S.L. 2007. From wildlife specialist to police generalist? The scope of nonwildlife violations encountered by conservation officers. Southwest Journal of Criminal Justice $4,120-132$.

Eliason, S.L. 1999. The illegal taking of wildlife: toward a theoretical understanding of poaching. Human Dimensions of Wildlife 4, 27-39.

Eliason, S.L. 2003a. Illegal hunting and angling: The neutralization of wildlife law enforcement. Society \& Animals 11, 225-243. 
Eliason, S.L. 2003b. Throwing the book versus cutting some slack: Factors influencing the use of discretion by game wardens in Kentucky. Deviant Behavior 24, 129-152.

Eliason, S.L. 2004. Accounts of wildlife law violators: Motivations and rationalizations." Human Dimensions of Wildlife 9, 119-131.

Eliason, S.L. 2008. Wildlife crime: conservation officer's perceptions of elusive poachers. Deviant Behavior 29, 111-128.

Eliason, S.L., \& Dodder, R.A. 2000. Neutralization among deer poachers. Journal of Social Psychology 140, 536-538.

Eliason, S.L., \& Dodder, R.A. 1999. Techniques of neutralization used by deer poachers in the western United States: A research note. Deviant Behavior 20, 233-252.

Falcone, D. 2004. America's conservation police: agencies in transition. Policing: An International Journal of Police Strategies \& Management 27, 56-66.

Filteau, M.R. 2008. The Warden is Comin': A Sociological Analysis of Poaching. Masters Thesis, University of Massachusetts Boston.

Forsyth, C.J. 1994. Bookers and Peacemakers: Types of game wardens. Sociological Spectrum, 14, 47-63.

Forsyth, C.J., Gramling, R., \& Wooddell, G. 1998. The game of poaching: Folk crimes in southwest Louisiana. Society \& Natural Resources 11, 25.

Forsyth, C.J. 1993. Chasing and Catching 'bad guys': The game warden's prey. Deviant Behavior 14, 209-226.

Forsyth, C. J., \& Marckese, T.A. 1993a. Thrills and skills: a sociological analysis of poaching. Deviant Behavior 4, 157-172.

Forsyth, C. J., \& Marckese, T.A. 1993b. Folk Outlaws: Vocabularies of motives. International Review of Modern Sociology 23, 17-31.

Forsyth, C.J., \& Forsyth, Y.A. 2009. Dire and sequestered meetings: The work of game wardens. American Journal of Criminal Justice 34, 213-223.

Geertz, C. 1973. The Interpretation of Cultures: Selected Essays. New York: Basic.

Gibbs, J. P. 1975. Crime, Punishment, and Deterrence. New York: Elsevier. 


\section{Deterring Defiance: 'Don't Give a Poacher a Reason to Poach' - Filteau}

Gibson, J.W. 2009. A Reenchanted World: The Quest for a New Kinship with Nature. New York, NY: Metropolitan Books.

Green, G.S. 1990. Resurrecting polygraph validation of self-reported crime data: A note on research method and ethics using the deer poacher. Deviant Behavior 11,131-137.

Green, G.S. 2002. The other criminalities of animal freeze-killers: Support for a generality of deviance. Society and Animals 10,5-30.

Hampshire, K., Bell, S., \& Topalidou, A. 2007. The political culture of poaching: a case study from northern Greece. Biodiversity and Conservation 16, 399-418.

Hampshire, K., Bell, S., Wallace, G., \& Stepukonis, F. 2004. Real poachers and predators: shades of meaning in local understandings of threats to fisheries. Society and Natural Resources 17, 305-318.

Heberlein, T. A. 1991. Changing attitudes and funding for wildlife-preserving the sport hunter. Wildlife Society Bulletin 19, 528-534.

Hirschi, T. 1969. Causes of Delinquency. Berkeley, CA: University of California Press.

Katz, J. 1988. Seductions of Crime. New York: Basic Books.

Lemieux, A. M. 2010. Policing poaching and protecting pachyderms: Lessons learned from Africa's elephants. In Rob I. Mawby \& Richard Yarwood (eds.), Rural Policing and Policing the Rural: A Constable Countryside? Burlington, VT: Ashgate Publishing, Ltd.

McSkimming, M.J., \& Berg, B.L. 2008. Motivations for citizen involvement in a community crime prevention initiative: Pennsylvania's TIP (turn in a poacher) program. Human Dimensions of Wildlife 13, 234-242.

Miles M. B., \& Huberman, A.M. 1994. Qualitative Data Analysis. Sage: Thousand Oaks: CA.

Musgrave, R.S., \& Stein, M.A. 1993. State Wildlife Laws Handbook. Rockville, MD: Government Institutes, Inc.

Musgrave, R.S., Parker, S., \& Wolok, M. 1993. Status of poaching in the United States-Are we protecting our wildlife? Natural Resources Journal. 33, 977-1014.

Muth, R.M. 1998. The persistence of poaching in advanced industrial society: meanings and motivations - an introductory comment. Society and Natural Resources 11, 5-7. 
Muth, R. M. \& Bowe, J.F. 1998. Illegal harvest of renewable natural resources in North America: Toward a typology of the motivations for poaching. Society \& Natural Resources 11, 9-24.

O’Connor S.T., \& Crow, M.S. 2009. The nature and extent of conservation policing: law enforcement generalists or conservation specialists? American Journal of Criminal Justice 34, 9-27.

O'Connor, M.T. 1986. Fishing for evidence: The expansive warrantless search powers of fish and game wardens. Hastings Const. LQ 13,119.

Palmer, C.E., \& Bryant C.D. 1985. Keepers of the king's deer. In C.D. Bryant, D.J. Shoemaker, J.K. Skipper, and W.E. Snizek (eds.), The Rural Workforce. South Hadley, MA: Bergin and Garvey.

Pendleton, M.R. 1996. Crime, criminals and guns in 'natural settings': exploring the basis for disarming federal rangers. American Journal of Police 15, 3-25.

Piquero, A R., Pogarsky, G. 2002. Beyond Stafford and Warr's reconceptualization of deterrence: Personal and vicarious experiences, impulsivity, and offending behavior. Journal of Research in Crime and Delinquency 39, 153 -186.

Rosen, G.E., \& Smith, K.F. 2010. Summarizing the evidence on the international trade in illegal wildlife. Ecohealth 7,24-32.

Ross, H.L. 1960. Traffic law violation: A folk crime. Social Problems 8, 231-241.

Scheff, T.J. and S.M. Retzinger. 1991. Emotions and violence: shame and rage in destructive conflicts. Lexington, MA: Lexington Books.

Sherblom, J., Keränen, L., \& Withers, L. 2002. Tradition, tension, and transformation: a structuration analysis of a game warden service in transition. Journal of Applied Communication Research 30, 143-162.

Sherman, L.W. 1993. Defiance, deterrence, and irrelevance: A theory of the criminal sanction. Journal of Research in Crime and Delinquency 30, 445.

Stafford, M. C., \& Warr, M. 1993. A Reconceptualization of General and Specific Detterrence. Journal of Research in Crime and Delinquency 30, 123-145.

Stretesky, P.B., O’Connor Shelley, T., \& Crow, M.S. 2010. Do conservation organizations influence the production of natural resource violations? Organization \& Environment 23, 398. 


\section{Deterring Defiance: 'Don't Give a Poacher a Reason to Poach' - Filteau}

Sunshine, J., \& Tyler, T. 2003. The Role of Procedural Justice and Legitimacy in Shaping Public Support for Policing. Law and Society Review 37, 513-548.

Sykes, G. M. , \& Matza, D. 1998. Techniques of neutralization: a theory of delinquency. American Sociological Review 47, 732-739.

Tyler, T. 1990. Why People Obey the Law. New Haven, CT: Yale University Press.

Tyler, T.R., \& Huo, Y.J. 2002. Trust in the Law. New York: Russell Sage.

U.S. Bureau of the Census. 2012. State Quick Facts. Washington, DC: Retrieved March 29, 2012. (http://quickfacts.census.gov/qfd/index.html).

Walsh, W.F., \& Donovan, E.J. 1984. Job stress in game conservation officers. Journal of Police Science \& Administration 12, 333-338.

Warchol, G.L. 2004. The transnational illegal wildlife trade. Criminal Justice Studies 17, 5773.

Warchol, G.L., Zupan, L.L., \& Clack, W. 2003. Transnational criminality: An analysis of the illegal wildlife market in Southern Africa. International Criminal Justice Review 13, 127. 